Mexico's Finance-Growth Nexus WITH TRADE OPENNESS, FDI AND PorTFOLIO INVESTMENT: EVIDENCE FROM VECM CoInTEGRATION ANALYSIS

El nexo del crecimiento financiero de México con la apertura comercial, la IED y la inversión de cartera: Evidencias del análisis de cointegración del modelo de corrección de errores vectoriales (VECM) 


\title{
Mexico's Finance-Growth Nexus with Trade Openness, FDI and Portfolio Investment: EvidenCE from VECM CoIntegration Analysis
}

\author{
El nexo del crecimiento financiero de México con la \\ apertura comercial, la IED y la inversión de cartera: \\ Evidencias del análisis de cointegración del modelo \\ de corrección de errores vectoriales (VECM)
}

Takashi Fukuda*

Keywords: Finance-growth nexus, Globalization, VECM, Cointegration, Mexico

Palabras clave: Nexo del crecimiento financiero, Globalización, VECM, Cointegración, México

JEL Classification: E44; F4O; 054

Received: 12/04/2019

Accepted: 19/12/2019

Published: 05/03/2020
*Academic level: Ph.D. in Economics,

Universiti Utara Malaysia.

takashi@fukuda-kieg.com

5-15-81-401, Toroku, Chuou-ku,

Kumamoto, 862-0970, Japan.

Independent researcher.

Orcid: 0000-0002-7108-1130

\section{Abstract}

This study investigates Mexico's finance-growth nexus by controlling the "globalization" variables of trade openness, foreign direct investment (FDI) and portfolio investment together with the structural break dummy. Financial development is proxied by two indicators of size and efficiency. Implementing the cointegration and Granger causality tests in the framework of the vector error correction model (VECM), we found that: financial size is negative for economic growth with no feedback; financial efficiency and economic growth are in a negative bilateral relationship; trade openness and portfolio investment are positive for economic growth; and FDI is negative for economic growth and financial efficiency.

\section{Resumen}

Este estudio analiza el nexo del crecimiento financiero de México al controlar las variables de la "globalización" de la apertura comercial, la inversión extranjera directa (IED) y la inversión de cartera junto con la variable ficticia de ruptura estructural. El desarrollo financiero es medido a través de dos indicadores: tamaño y eficiencia. Al implementar las pruebas de cointegración y de causalidad de Granger en el marco del modelo de corrección de errores vectoriales (VECM), encontramos que: el tamaño financiero es negativo para el crecimiento económico sin retroalimentación, la eficiencia financiera y el crecimiento económico tienen una relación bilateral negativa, la apertura comercial y la inversión de cartera 
son positivas para el crecimiento económico, y la IED es negativa para el crecimiento económico y la eficiencia financiera.

\section{INTRODUCTION}

Since Schumpeter (1911) argued that a well-developed financial system is important to attain higher economic growth through technological innovations, the relationship between financial development and economic growth has been extensively investigated in literature. Theoretical literature predicts that economic growth is a positive function of financial development as financial markets are productive to stimulate an economy by providing essential services through two channels. The first one is the accumulation channel which emphasizes the growth-driving effects of physical and human capital accumulation (e.g. Pagano, 1993). The other is the allocation channel which focuses on a financeinduced increase in the efficiency of resource allocation and its growth-enhancing effects (e.g. King and Levine, 1993a). While the growth effect of financial deepening has been theoretically acknowledged, it is necessary to empirically address the issue of the finance-growth nexus, that is, whether/how financial development significantly influences economic growth.

The objective of the present study is to investigate the relationship between financial development and economic growth in Mexico by conducting a country specific in-depth analysis with the vector error correction model (VECM) approach. To the end we implemented the cointegration and the Granger causality tests in the VECM framework to give interference to Mexico's finance-growth nexus. We contribute to literature by filling the following gaps. First, as far as time series studies examining the causal linkage between finance and economic growth are concerned, since the use of a bivariate causality analysis was very standard in the past, such empirical studies of finance and output variables were only more likely to have the omission-of-variable bias. It has been pointed out that a country's finance-growth linkage is a more complicated phenomenon highly depending on other variables than finance and output because a growth-enhancing financial system requires a far-reaching spectrum of structural reforms and policy measures (Cevik and Rahmati, 2018), otherwise the omission of such variables could lead to misspecification (Luintel and Khan, 1999). We analyzed Mexico's financegrowth nexus in terms of globalization - trade openness, foreign direct investment (henceforth FDI) and portfolio investment - together with a structural break. Mexico is a good sample country having various experiences of developing and liberalizing its financial system and external sector together with several financial crises, but the extant literature has not yet extensively and properly explored whether/how Mexico's finance-growth nexus is influenced by ongoing globalization.

Second, we are also concerned with the issue of measuring financial development in the present study. Most empirical studies have used the size-based financial indicators, whose rationale is that more credit and funding are directly linked to more efficient allocation. However, it has been increasingly questioned whether those size indexes, which are mostly measured by the ratio of total domestic credit or various monetary aggregates to nominal GDP, are suitable to measure the effect of financial development (Wachtel, 2011); the redefinition of financial measures is proposed to overcome the shortcomings of commonly used measures (Čihák et al., 2013). Considering these arguments of "what is financial development?", we employed the two financial indicators of size and efficiency in assessing Mexico's finance-growth nexus.

The rest of the paper is structured as follows. The related literature is reviewed in Section 2. Our study's theoretical models and data are given in Section 3, and methodology is elucidated in $\underline{\text { Section }}$ 4. Empirical findings are reported and discussed in Section 5, and $\underline{\text { Section } 6}$ concludes. 


\section{LITERATURE REVIEW}

\subsection{Finance-growth nexus debate}

In investigating the relationship between financial development and economic growth, whether/ how the two variables influence each other is one important topic. In regards to this, Patrick (1966) suggests different directions, i.e. either "supply-leading" (finance $\rightarrow$ growth) or "demand-following" (growth $\rightarrow$ finance) or "bilateral" (finance $\rightarrow$ growth) throughout the development process. The supplyleading hypothesis virtually coincides with theoretical achievements of McKinnon (1973) and $\underline{\text { Shaw }}$ (1973), that is, financial institutions utilize productive resources to facilitate capital formation and thus play a crucial role in mobilizing, saving and in allocating thus collected resources efficiently to productive sectors. Over the 1950 os and 196os, conventional policy advice was that governments in developing countries actively promoted development by intervening in financial markets. By the early 1970s, the so-called financial repression was brought to literature by McKinnon (1973) and Shaw (1973) who were in favour of liberalizing the financial system while criticizing such repression policies as ceilings on interest rates, high reserve requirements and administrative credit allocation.

In contrast, according to the demand-following hypothesis, since financial depth can be enhanced by output growth, financial development is just a phenomenon in response to the increasing demand for new financial instruments and service. While an economy grows, such a demand will spontaneously rise and result in the evolution of an economy's financial system. As Robinson (1952) mentions that 'where enterprise leads finance follows'. Since the increasing demand for financial services is brought by economic growth, it is economic growth that is the chief driving force behind financial deepening and the growth effect of finance is overstressed (Lucas, 1988).

Additionally, the other view is that finance and growth may be interdependent, i.e. the bilateral relationship where financial development and economic growth have an impact on each other (finance $\leftrightarrow$ growth) (e.g. Demetriades and Hussein, 1996). While a well-developed system is essential for economic growth, the latter is also necessary for the former as financial markets effectively respond to the demand for certain financial instruments and services which are created by economic expansion' ${ }^{1}$.

We observed that empirical studies analyzing the issue of the finance-growth nexus have the following issues. First, while the leading evidence of financial development positively impacting economic growth is presented by cross-country studies (e.g. King and Levine, 1993b; Levine and Zervos, 1998), some economists critically argue that those studies are implicitly based on the assumption of homogeneity in different countries' growth patterns, thus hiding country-specific factors in estimation (e.g. Demetriades and Hussein, 1996; Luintel and Khan, 1999). Second, as far as time series studies are concerned - in which the Granger causality between financial development and economic growth is usually conducted to give interference--, since the use of a bivariate causality test was standard in assessing the finance-growth nexus, previous studies of "finance and growth only" were likely to suffer from the omission-of-variable bias. It is considered that other variables might exhibit significant impact on the finance-growth nexus; the omission of such variables could bias the direction of causality between financial development and economic growth. As a result, an increasing number of empirical studies have introduced various third and more variables to the estimation of the finance-growth causality.

1There are also other predictions for the finance-growth nexus. Chandavarkar (1992) argues that financial development and economic growth may not relate to each other. 


\subsection{Globalization}

On the other hand, as globalization rapidly goes on worldwide, how trade openness, FDI and portfolio investment impact on economic growth is widely discussed and investigated in literature. While the growth effect of trade (export and import) has been traditionally recognized (e.g. Yanikkaya, 2003), those of FDI and portfolio investment are discussed differently. FDI produces externalities through the diffusion of new technology and of business know-how. Thus, FDI is expected to exhibit considerable spillover effects to enhance the productivity of an economy in the long run. Meanwhile, portfolio investment can promote economic growth by increasing the liquidity of financial markets. As domestic markets become more liquid, deeper and broader, a wider range of projects can be financed more efficiently in the short run (De Vita and Kyaw, 2009).

While these two types of investment become available for developing countries, international agencies have advised developing countries to rely mainly on FDI (Nunnenkamp and Spatz, 2004). One of the reasons is the frequency of "financial crisis" and "boom-and-bust" cycles (Durham, 2004) observed in emerging economies. Rapid financial deepening typically leads to growth volatility, financial instability and financial crisis. More liquid financial markets due to the increasing volume of portfolio investment - associated with speculation activities - significantly cause higher vulnerability to international shocks, resulting in a financial crisis that brought a severe negative impact on an economy. Indeed, there are several crisis episodes in the developing world, such as India in 1991, Asian countries in 1997-1998 and Argentina in 2000.

\subsection{Mexico's experiences}

Our sample country is Mexico that has attempted a variety of liberalization policies for economic development so far, but its growth achievement has been low with the standard of emerging economies over the last decades. Mexico initiated its opening to the global economy by promoting oil exports and borrowing from international banks in the late 1970 (Blecker, 2009). But this strategy was very unsuccessful as Mexico was to default on its sovereign debt in 1982 due to an unfortunate combination of expansionary monetary and fiscal policies, sharp deterioration in international oil markets, strong capital outflows, and the peso devaluation (Tinoco-Zermeno, Martinez and Torres-Preciado, 2014). The Mexican government indeed abandoned import substitution by joining the General Agreement on Tariffs and Trade (GATT) in 1986 and the North American Free Trade Agreement (NAFTA) in 1994. Specifically, after NAFTA was formed with Canada and the US, "maquiladora (export assembly plant)" was the key word enabling Mexico to become a major trader and FDI recipient ${ }^{2}$. It should be pointed out that NAFTA was an important instrument behind the surge of exports and FDI in the late 1990 (Moreno-Brid et al., 2005). Meanwhile, by the end of the 1990s, the Mexican government also started several economic and financial reforms to open up the economy to foreign competition in goods and capital markets, as well as to release domestic financial markets from government intervention.

Despite its opening up to the global market, Mexico's growth performance has been acknowledged as unremarkable in comparison with those of Asian countries. In particular, as China's manufacturing export quickly expanded worldwide after the country joined the World Trade Organization (WTO) in 2001, the number of Mexico's export plants reduced significantly. On the other hand, Mexico was chronically exposed to the increasing extent of financial fragilities and shocks over the last few decades;

2 Maquiladoras are responsible for approximately half of the manufactured goods exported by Mexico and rely fundamentally on imported inputs and materials, resulting in a limited relationship with local suppliers (Moreno-Bird, Napoles and Valdivia, 2005). 
Mexico's various policies of opening and liberalization have made the country highly vulnerable to external shocks since late 1970 (Blecker, 2009). One well-known episode is that Mexico was hit by a financial crisis in 1994-1995 immediately after NAFTA began. The 2008 financial crisis of the United States jeopardized Mexico more severely than any other Latin America countries (Cypher, 2011). On those occasions, there might have been too much finance whose costs typically overweighed the benefits of financial development and liberalization. These profiles of Mexico motivated us to empirically confirm whether financial development - interacting with trade openness, FDI and portfolio investment-is really good or bad for the Mexican economy.

\section{THEORETICAL MODELS AND DATA}

Based on our objective and the considerations discussed in the previous section, we specify the theoretical models to analyze Mexico's finance-growth nexus as follows:

$$
\begin{aligned}
& E G_{t}=f_{1}\left(F S_{t}, T O P_{t}, F D I_{t}, P F I_{t}\right) \\
& E S_{t}=f_{2}\left(E G_{t}, T O P_{t}, F D I_{t}, P F I_{t}\right) \\
& E G_{t}=f_{3}\left(F E_{t}, T O P, F D I_{t}, P F I_{t}\right) \\
& F E_{t}=f_{4}\left(E G_{t}, T O P_{t}, F D I_{t}, P F I_{t}\right)
\end{aligned}
$$

We conducted the Granger causality tests to investigate the relationship between the economic growth indicator (real per capita GDP, EG) and each of the financial development indicators (FS and FE). The indicators of trade openness (TOP), FDI (FDI), portfolio investment (PFI) are also included to avoid the omission-of-variable bias in assessing Mexico's finance-growth nexus. The inclusion of these variables of "globalization" would be meaningful as Mexico has been one of the important trading countries, and the enhancement of FDI and portfolio investment-not trade-is the prime motivation of Mexico's entering into NAFTA (ameron and Tomlin, 2000). ${ }^{3}$

In Equations 1 and 2, EG and FS are treated as the dependent variables, respectively, to confirm whether/how economic growth and financial size are related to each other, that is, the causality runs either $\mathrm{FS} \rightarrow \mathrm{EG}$ or $\mathrm{EG} \rightarrow \mathrm{FS}$ or $\mathrm{FS} \leftrightarrow \mathrm{EG}$. Likewise, the causality of either $\mathrm{FE} \rightarrow \mathrm{EG}$ or $\mathrm{EG} \rightarrow \mathrm{FE}$ or $\mathrm{FE} \leftrightarrow \mathrm{EG}$ - whether/how economic growth and financial efficiency Granger-cause each other- are examined in Equations 3 and 4 where EG and FE are taken as the dependent variables, respectively.

The financial size index is a quantitative measure of financial development which is proxied by the GDP ratio of domestic credit to the private sector provided by commercial banks. As a qualitative measure of financial depth, the financial efficiency index is represented by the ratio of domestic credit to the private sector provided by banks to the private sector to the gross domestic savings. Originally, Beck, Demirgüç-Kunt and Levine (2009) suggested the ratio of private credit to total deposit (demand + time deposits) though, the continuous series of Mexico's total deposit is not available, so we use the 
gross domestic savings. ${ }^{4}$ Trade openness is measured by the GDP ratio of the sum of exports and imports of goods and services. "FDI" is the GDP ratio of the net flows of FDI. Portfolio investment is the GDP ratio of net flows through cross-border public and publicly guaranteed and private nonguaranteed bond issues. All the underlying variables are converted into logarithm. For this analysis, we drew annual data series mainly from the World Bank's World Development Indicators (WDI) and from the IMF's International Financial Statistics (IFS). The sample period ranges from 1970 to 2016 over which Mexico's development strategy greatly changed from an import substitution one to a market-oriented one.

\section{METHODOLOGY}

\subsection{VECM specification}

As we employed the cointegration approach of Johansen (1988), the formal specification of the vector error correction model (VECM) with weakly exogenous variables for Mexico's finance-growth nexus is given as follows:

$$
\mathrm{X}_{t}=\Pi Y_{t-p}+\Gamma_{1} \Delta Y_{t-1}+\Gamma_{2} \Delta Y_{t-2}+\cdots+\Gamma_{p-1} \Delta Y_{t-p+1}+u_{t}
$$

In Equation (5), $X_{t}=[\mathrm{EG}, \mathrm{FS} / \mathrm{FE}]$ is a $2 \times 1$ vector of the endogenous $/$ dependent variables; $Y_{t}=[\mathrm{EG}$, FS/FE, TOP, FDI, PFI] is the cointegrating vector of the endogenous and weakly exogenous variables; $p$ is the lag order included in the system; $\Gamma_{i}$ refers to short-run coefficient matrices; and $u_{t}$ is a vector of error terms. The cointegrating relationship between the endogenous/dependent variables is given by the rank of $\Pi$ matrix $(r)$ in which o $<r<2$. The two matrices $\alpha$ and $\beta$ with dimension $(2 \times r)$ are such that $\alpha \beta^{\prime}=\Pi$. The matrix $\beta$ contains the $r$ cointegrating vectors, having the property that $\beta^{\prime} Y_{t}$ is stationary. $\alpha$ is the matrix of the error correction presentation that shows the speed of adjustment from a short-run disequilibrium to a long-run steady state equilibrium. Assuming a single cointegrating vector $(r=1)$ in the assessment, we provide the following system equations:

$$
\begin{aligned}
& {\left[\begin{array}{l}
\Delta E G_{t} \\
\Delta F S_{t}
\end{array}\right]=\left[\begin{array}{l}
\alpha_{1 j} \\
\alpha_{2 j}
\end{array}\right]\left[\beta_{i 1} \beta_{i 2} \beta_{i 3} \beta_{i 4} \beta_{i 5}\right]\left[\begin{array}{c}
E G_{t-1} \\
F S_{t-1} \\
T O P_{t-1} \\
F D I_{t-1} \\
P F I_{t-1}
\end{array}\right]+\Gamma_{i j}\left[\begin{array}{c}
\Delta E G_{t-p} \\
\Delta F S_{t-p} \\
\Delta T O P_{t-p} \\
\Delta F D I_{t-p} \\
\Delta P F I_{t-1}
\end{array}\right]+\left[\begin{array}{l}
\hat{u}_{1 t} \\
\hat{u}_{2 t}
\end{array}\right]} \\
& {\left[\begin{array}{l}
\Delta E G_{t} \\
\Delta F E_{t}
\end{array}\right]=\left[\begin{array}{l}
\alpha_{3 j} \\
\alpha_{4 j}
\end{array}\right]\left[\beta_{i 6} \beta_{i 7} \beta_{i 8} \beta_{i 9} \beta_{i 10}\right]\left[\begin{array}{c}
E G_{t-1} \\
F E_{t-1} \\
T O P_{t-1} \\
F D I_{t-1} \\
P F I_{t-1}
\end{array}\right]+\Gamma_{i j}\left[\begin{array}{c}
\Delta E G_{t-p} \\
\Delta F E_{t-p} \\
\Delta T O P_{t-p} \\
\Delta F D I_{t-p} \\
\Delta P F I_{t-1}
\end{array}\right]+\left[\begin{array}{l}
\hat{u}_{3 t} \\
\hat{u}_{4 t}
\end{array}\right]}
\end{aligned}
$$

Equation 6 is "Model I" whose financial development indicator is the financial size (FS), and Equation 7 is "Model II" whose financial development indicator is the financial efficiency (FE). In the two equations, EG and FS/FE are the endogenous/dependent variables, whereas TOP, FDI and PFI are treated as weakly exogenous variables in the cointegrating vector.

4 Like other developing countries, it is assumed that bank credit-not stock market transactions-is dominant in Mexico's financial development. Also, as compared with stock market indexes, banking ones are more available over a longer time period. 
By normalizing each of EG and FS/FE, we implement two types of the Granger causality test in the VECM estimation. The first test is the weak exogeneity test that imposes zero restrictions on $\alpha$, i.e. $\mathrm{H}_{0}: \alpha_{i j}=0$; the rejection of the null hypothesis indicates that there is a long-run causality formed by all the underlying variables in the system (Johansen and Juselius, 1992). The second test is the strong exogeneity test that is related to an overall causality by imposing a restriction on both $\alpha$ and either of $\beta$, i.e. $\mathrm{H}_{0}: \alpha_{i j} \beta_{i j}=0$ (Toda and Phillips, 1993). Referring to the significant results of these two tests, we gave interference to Mexico's finance-growth nexus.

\subsection{Structural break dummy}

Importantly, referring to the argument of Johansen, Mosconi and Nielsen (2000), we took the element of structural break - in the form of a level shift dummy - into the VECM assessment. The rationale is that by taking structural breaks into estimation, macroeconomic instability that Mexico experienced over the sample period might be well reflected, so that all the underlying variables collectively explain most variations in Mexico's finance-growth nexus and allowed us to seek a single cointegration $(r=1)$ and no autocorrelation. To this end, break dates in Mexico's EG (real per capita GDP) series are estimated by the structural break test developed by Lee and Strazicich (2003; 2004) (hereafter the LS test).

The LS test is a Lagrange multiplier unit root test that endogenously pinpoints at most two breaks in each series. We employ Models A and AA which provide an abrupt change in level but no change in the trend rate. Based on the break dates given by Models A and AA in Table 1, we made level shift dummies (LSD) and plot either of 1983LSD or 1983LSD and 1994LSD. 5 While endogenously detected by the LS test, the break dates in Table 1 seem to reasonably correspond to such important events as the 1982-1983 debt crisis, the 1994-1995 financial crisis and the inauguration of NAFTA.

Table 1: Break dates in Mexico's EG series

\begin{tabular}{l|c}
\multicolumn{1}{c|}{ Model } & Break date(s) \\
\hline A (one break) & 1983 \\
\hline AA (two breaks) & 1983 \\
\hline & 1994 \\
\hline
\end{tabular}

Notes: Models A and AA = the clash models (break(s) only in the intercept).

\section{Empirical Results}

\subsection{Initial procedures}

Performing the VECM cointegration analysis for Mexico's finance-growth nexus, we first conducted two unit root tests of the GLS augmented Dickey-Fuller (ADF-GLS) test (Elliott, Rothenberg and Stock, 1996) and the Phillips and Perron (PP) test (Phillips and Perron 1988). The ADF-GLS test is better than the standard Dickey-Fuller test as the former is based on a modified statistics of the latter with generalized least squares (GLS). On the other hand, the PP test is an alternative to the ADFGLS test as the PP test's residual variance is robust to autocorrelation. Table 2 reports that EG, FS, FE, TOP, FDI and PFI are estimated as non-stationary in their levels but are stationary after taking their first-differences at the $10 \%$ level or better. Referring to those statistics, we considered all the underlying variables adequate for the analysis.

5 Lee and Strazicich (2003; 2004) also suggest Models B and BB which allow for simultaneous changes in level and trend. However, since such changes are not properly taken into our analysis, we do not provide the break dates given by Models B and BB. 
Next the Johansen (1988) cointegration test, whose lag order is set at two by considering the sample size of the present study, is implemented. ${ }^{6}$ While TOP, FDI and PFI are taken as the weakly exogenous variables, both LSD and an intercept are included as the deterministic components in the cointegrating vector. After checking all possible combinations of the deterministic components, we confirmed that an intercept and two LSDs (1983LSD and 1994LSD) are good for Model I to draw more plausible estimates. According to trace statistics in Table 3, there is a single cointegration relationship $(r=1)$ in Model I at the $1 \%$ significance level. In the same way, an intercept and one LSD (1983LSD) are taken into Model II, and a single cointegration relationship is found at the $1 \%$ significance level. ${ }^{7}$ Before discussing empirical results, we check the diagnostic test statistics of autocorrelation, nonnormality and heteroscedasticity in Table 4 and judge the two models of the VECM analysis adequate for considering Mexico's finance-growth nexus.

Table 2: Unit root test results $(k=2)$

\begin{tabular}{|c|c|c|c|c|}
\hline & \multicolumn{2}{|c|}{ ADF-GLS Test } & \multicolumn{2}{|c|}{ PP Test } \\
\hline & Inpt. & Inpt. \& trend & Inpt. & Inpt. \& trend \\
\hline$E G$ & 0.201 & -2.056 & -1.968 & -2.619 \\
\hline$\triangle E G$ & $-3.431 * * *$ & $-3.886 * * *$ & $-5.383^{* * *}$ & $-5.435 * * *$ \\
\hline FS & -1.589 & -1.693 & -2.020 & -1.637 \\
\hline$\triangle \mathrm{FS}$ & $-2.691^{* *}$ & $-3.044^{*}$ & $-7.327^{* * *}$ & $-7.572 * * *$ \\
\hline FE & -1.485 & -1.697 & -2.203 & -1.921 \\
\hline$\triangle \mathrm{FE}$ & $-3.185^{* * *}$ & $-3.536^{* *}$ & $-6.752^{* * *}$ & $-6.881 * * *$ \\
\hline TOP & 0.665 & -3.278 & -0.660 & -3.458 \\
\hline$\triangle T O P$ & $-4.893^{* * *}$ & $-4.865 * * *$ & $-6.101^{* * *}$ & $-6.022^{* * *}$ \\
\hline FDI & -0.728 & -1.956 & -1.585 & -4.686 \\
\hline$\Delta \mathrm{FDI}$ & $-3.540 * * *$ & $-3.945 * * *$ & $-12.490^{* * *}$ & $-12.309 * * *$ \\
\hline $\mathrm{PFI}$ & -1.791 & -2.582 & $-2.679 *$ & $-3.530^{* *}$ \\
\hline$\triangle P F I$ & $-3.242^{* * *}$ & $-3.254^{* *}$ & $-9.852^{* * *}$ & $-9.738 * * *$ \\
\hline
\end{tabular}

Notes: $(* * *) 1 \%,(* *) 5 \%$ and $(*) 10 \%$ level of significance. 
Table 3: VECM cointegration test results

\begin{tabular}{lllll} 
Model I & & & \\
Dependent variables & I (1) exo. variables & Det. components & Null & p-value \\
\hline EG & TOP & Intercept (rest.) & $r=0$ & $0.008^{* * *}$ \\
FS & FDI & 1983LSD (rest.) & $r<=1$ & 0.218 \\
Model II & 1994LSD (rest.) & & \\
Dependent variables & I (1) exo. variables & Det. components & Null & -value \\
\hline EG & TOP & Intercept (rest.) & $r=0$ & $0.002^{* * *}$ \\
FE & FDI & 1983LSD (rest.) & $r<=1$ & 0.093 \\
\hline & PFI & &
\end{tabular}

Notes: $\left.{ }^{* * *}\right) 1 \%$ level of significance. The results are based on critical values simulated with 400 random walks and 2500 replications.

Table 4: Diagnostic test results

\begin{tabular}{l|l|l}
\multicolumn{1}{c|}{ Test } & \multicolumn{1}{c|}{ Model I } & \multicolumn{1}{c}{ Model II } \\
\hline Autocorrelation & $4.075[0.396]$ & $6.320[0.177]$ \\
\hline Normality & $9.160[0.057]$ & $5.476[0.242]$ \\
\hline Heteroscedasticity & $3.224[1.000]$ & $8.741[0.965]$ \\
\hline
\end{tabular}

Notes: The results are based on $X^{2}$ statistics. For autocorrelation and heteroscedasticity, LM(2) statistics are reported. In parentheses p-values are provided.

\subsection{Identified cointegrating vectors}

Table 5 shows identified cointegrating vectors for economic growth and financial size/financial efficiency together with $\alpha$ and weak exogeneity test statistics. " $\alpha$ " is the ECT (error correction term) coefficient that shows the speed of adjustment back to the long-run equilibrium whenever there is a deviation from a steady state in the system. In this regards, the ECT coefficient should be statistically significant with a negative sign. As given by the weakly exogenous test, all the ETC coefficients - except for the case in which FS is the dependent variable - are the $1 \%$ level significant holding a negative sign together with an acceptable size. By normalizing the coefficient of EG/FS/ FE to one in the cointegrating vector, we check the direction of each underlying variable with respect to the three dependent variables, i.e. whether one variable is either positive or negative to economic growth/financial size/financial efficiency by looking at each variable's sign in the cointegrating vector. While those negative directions of FS $\rightarrow$ EG and EG $\rightarrow$ FS are detected in Model I, the latter's ECT is not statistically significant. In case of Model II, we find two negative directions of FE $\rightarrow$ EG and EG $\rightarrow$ FE. As far as the directions of the weakly exogenous variables are concerned, those are the same in the two models, that is, TOP is positive for EG/FS/FE, FDI is negative for EG/FS/FE, and PFI is positive for EG/FS/FE, respectively. 
Table 5: Cointegrating vectors

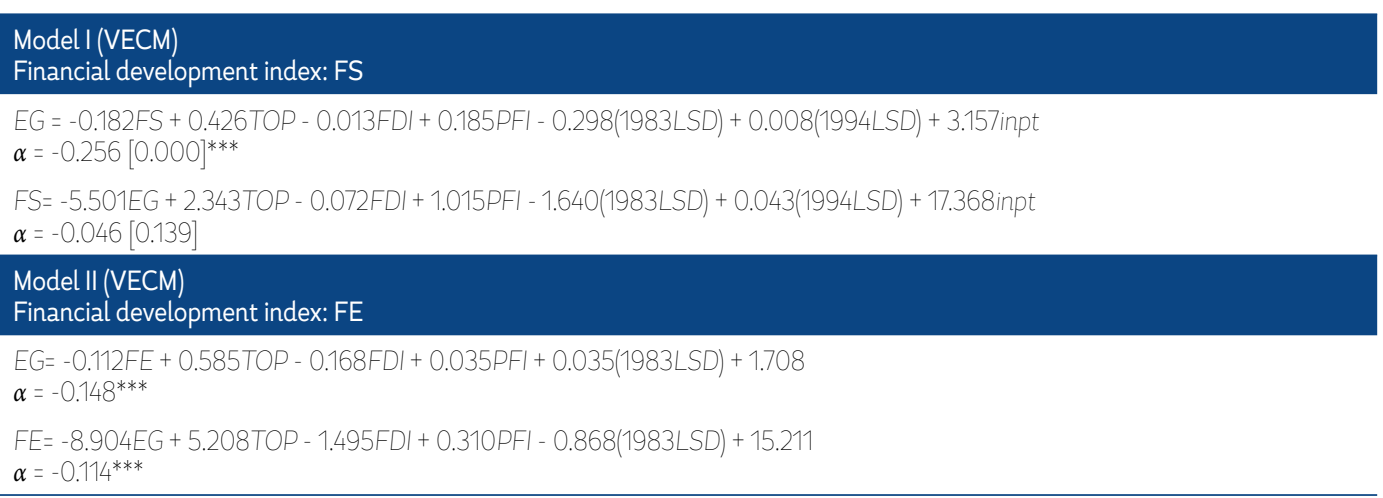

Notes: (***) $1 \%$ level of significance. The significance of (ETC coefficient) is given by the weakly exogeneity test.

\subsection{Granger causality test results}

The strong exogeneity test statistics are presented in Tables 6 and 7 whose third columns report the direction of impact given by referring to the sign of each underlying variable in the cointegrating vector (see Table 5). Based on the significant results of the strong exogeneity test, we determined the causal direction of each underlying variable in Mexico's finance-growth nexus. First of all, the findings of Model I, whose financial development indicator is FS, reveal a negative unilateral causality from financial size to economic growth at the $1 \%$ significance level. Although the result of the case in which FS is the dependent variable indicates a negative causality from economic growth to financial size in Table 6, we cautiously do not take it to give interference as the ECT coefficient is statistically insignificant $(p=0.139)$ in the weak exogeneity test. ${ }^{8}$ On the other hand, the findings of Model II, whose financial development indicator is $\mathrm{FE}$, indicate a negative two-way causality between economic growth and financial efficiency at the $5 \%$ significance level or better. The "deceleration" effect of economic growth to financial efficiency $(-8.904)$ is much larger than that of financial efficiency to economic growth (-0.112), implying that more output makes the financial system more inefficient in Mexico. Thus, the two VECM specifications of different financial development indicators exhibit different causal directions and support such an argument that Mexico's stagnation is largely caused by its inefficient financial system (Kehoe and Ruhl, 2010).

We also highlight the results of the weakly exogenous variables (trade openness, FDI and portfolio investment) either on economic growth or on financial size or on financial efficiency. Trade openness has a positive impact on economic growth in both Models I and II, and is also positive for financial efficiency in Model II. Unexpectedly, the results of FDI show that FDI discourages economic growth in both Models I and II and financial efficiency in Model II. With regards to portfolio investment, while it encourages economic growth in both Models I and II, we obtained no meaningful result on the causality from portfolio investment to financial size/financial efficiency. 
Table 6: Causality test results (Model I)

\begin{tabular}{|c|c|c|}
\hline Regressors & Result & Causal direction \\
\hline ECT(-1) & \multicolumn{2}{|l|}{ CHISQR(1) $=17.046[0.000]^{* * *}$} \\
\hline FS \& ECT(-1) & CHISQR(2) $=17.600[0.000]^{* * *}$ & Negative \\
\hline TOP \& ECT(-1) & CHISQR(2) $=22.084[0.000]^{* * *}$ & Positive \\
\hline FDI \& ECT(-1) & CHISQR(2) = $17.344[0.000]^{* * *}$ & Negative \\
\hline$P F I \& E C T(-1)$ & CHISQR(2) $=17.046[0.000]^{* * *}$ & Positive \\
\hline \multicolumn{3}{|c|}{$H_{0}:$ EG/TOP/FDI/PFI does not cause FS. } \\
\hline Regressors & Result & Causal direction \\
\hline ECT(-1) & \multicolumn{2}{|l|}{ CHISQR(1) = $2.194[0.139]$} \\
\hline$E G \& E C T(-1)$ & CHISQR(2) = $12.059[0.002]$ & Negative \\
\hline TOP \& ECT(-1) & CHISQR(2) = $7.868[0.020]$ & Positive \\
\hline$F D \mid \& E C T(-1)$ & CHISQR(2) = $2.197[0.333]$ & Negative \\
\hline$P F \mid \& E C T(-1)$ & CHISQR(2) = $3.068[0.216]$ & Positive \\
\hline
\end{tabular}

Notes: $\left.{ }^{* * *}\right) 1 \%$ level of significance. Although the results of the case where FS is the dependent variable are reported, those are not considered to give interference as the ECT coefficient is statistically insignificant.

Table 7: Causality test results (Model II)

\begin{tabular}{|c|c|c|}
\hline Regressors & Result & Causal direction \\
\hline ECT(-1) & \multicolumn{2}{|l|}{ CHISQR(1) $=6.572^{* * *}$} \\
\hline $\mathrm{FE} \& \mathrm{ECT}(-1)$ & CHISQR(2) = 8.359** & Negative \\
\hline TOP \& ECT(-1) & $\operatorname{CHISQR}(2)=14.349^{* * *}$ & Positive \\
\hline FDI \& ECT(-1) & CHISQR(2) $=11.875^{* * *}$ & Negative \\
\hline$P F \mid \& E C T(-1)$ & $\operatorname{CHISQR}(2)=6.787^{* *}$ & Positive \\
\hline \multicolumn{3}{|c|}{$H_{0}:$ EG/TOP/FDI/PFI does not cause FE. } \\
\hline Regressors & Result & Causal direction \\
\hline ECT(-1) & \multicolumn{2}{|l|}{ CHISQR $(1)=10.185^{* * *}$} \\
\hline $\mathrm{EG} \& \mathrm{ECT}(-1)$ & CHISQR(2) = 16.599*** & Negative \\
\hline TOP \& ECT(-1) & CHISQR(2) $=13.790^{* * *}$ & Positive \\
\hline FDI \& ECT(-1) & CHISQR(2) $=10.258^{* * *}$ & Negative \\
\hline$P F I \& E C T(-1) \S$ & \multicolumn{2}{|l|}{ CHISQR(2) = } \\
\hline
\end{tabular}

Notes: $\left(^{* *}\right) 1 \%$ and $\left(^{* *}\right) 5 \%$ level of significance. (§) Since the chosen normalization invalidates calculation of the "standard error" for beta, the result is not provided. 


\subsection{Discussion}

According to the empirical findings of the present study, although Mexico promoted financial development and opened up to the global economy over the sample period from 1970 to 2016, the restraints on Mexico's economic growth have not been removed yet. The phenomenon of financial deepening and globalization in Mexico - the growth effect of trade openness is confirmed, whereas those of financial size, financial efficiency and FDI are negative-seems to be very complicated. Thus, our findings are different from theoretical expectations. Based on those heterogeneous and unexpected findings, we argue that just encouraging financial development and globalization is obviously dangerous, simply suspecting the past crises might be brought about by such a nature of the Mexican economy. It is mentioned that the deregulation of the Mexican financial system caused a contraction of credit for productive activities and deepened the rentier and speculative character of Mexico's commercial banking (Lopez and Basilio, 2016). Furthermore, Sahay et al. (2015) point out that "too-much" finance actually reduces economic growth while increasing the frequency of booms and busts and leaves countries ultimately worse off and with lower real GDP growth. As the low degree of financial intermediation has been one feature of the Mexican economy (Herman and Klemm, 2017), we observed that Mexico's institutional ability is not enough to manage the financial system efficiently and prudentially.

\section{Conclusions}

A number of empirical studies have been conducted on the finance-growth nexus in developing countries (especially those in Asian countries), but there are only a few studies on the same topic of Mexico. We implement an in-depth case study for Mexico's finance-growth nexus in the VECM framework by employing such globalization variables as trade openness, FDI and portfolio investment together with a structural break and by taking each of financial size and financial efficiency -as the dependent variable - into estimation. The prime discovery of the present study is that financial size - the GDP ratio of domestic credit to the private sector provided by banks - exerts a negative impact on economic growth with no feedback from the latter to the former. Another finding is that economic growth and financial efficiency - the ratio of domestic credit to the private sector provided by banks to the private sector to the gross domestic savings - are negatively related to each other. From these results, we observed that Mexico's finance-growth nexus is "supply-retarding" when financial development is proxied by its size but "retarding each other" when financial efficiency is the indicator; these findings of our study do not follow a standard prediction of financial development contributing to higher economic growth. As far as the globalization variables are concerned, we detected a set of diverse results, that is, the growth effects of trade openness and portfolio investment are surely confirmed in the two models, whereas FDI negatively contributes to economic growth and financial efficiency indicating that the expected growth-promoting technology transfer has not been brought by FDI in Mexico. ${ }^{9}$

A key policy implication of the present study is that policy makers should consider how to convert the negative effects of financial development and FDI detected in Mexico's finance-growth nexus into positive ones, otherwise such a growth-retarding mechanism -in which the positive effect of trade might be offset - will remain, leaving Mexico a low growth country. In order to achieve sustainable economic growth, policy makers need to identify what is essential to reform its inefficient economic

9 The negative growth effect of FDI might be associated with the argument that FDI flows can have a negative impact on economic growth if those cause reverse flows in the form of remittances of profits and dividends (Ramirez, 2006). 
structure, always taking into account such external factors as the geological closeness to the United States and the increasing trade competition with China. Otherwise, a low expectation about Mexico's future economic growth will continuously exist. There must be a growth-promoting way to achieve financial development and globalization without instability. Finally, we emphasize that conducting a country-specific analysis is important to empirically address the issue of the finance-growth nexus which might be largely determined by the nature of each country's own institutional and structural characteristics. In particular, although the finance-growth linkage has been considered as strictly positive and linear, as our Mexican findings show, it could be negative and nonlinear. A new consensus has emerged in literature, that is, there is an inverted U-shaped relationship between financial development and economic growth (Carré and L'œillet, 2018). While our approach to Mexico's finance-growth nexus using VECM cointegration technique is applicable to other countries, future studies need to properly deal with the issue of nonlinearity. 


\section{REFERENCES}

Beck, T., Demirgüç-Kunt, A. \& Levine, R. (2009). Financial institutions and markets across countries and over time: data and analysis. World Bank Policy Research Working Paper, no.4943. Washington DC: World Bank.

Blecker, R. A. (2009). External shocks, structural change, and economic growth in Mexico, 1979-2007. World Development, 37 (7), 1274-1284.

Cameron, M. \& Tomlin, B. (2000). The Making of NAFTA. New York: Cornell University Press.

Carré, E. \& L'œillet, G. (2018). The literature on the finance-growth nexus in the aftermath of the financial crisis: a review. Comparative Economic Studies, 60 (1), 161-180.

Cevik, S. \& Rahmati, M. H. (2018). Searching for the finance-growth nexus in Libya. Empirical Economics, First Online: 31 December, 1-15.

Chandavarkar, A. (1992). Of finance and development: neglected and unsettled questions. World Development, 20 (1), 133-142.

Cheung, Y. \& Lai, K. (1993). Finite-sample sizes of Johansen's likelihood ratio tests for cointegration. Oxford Bulletin of Economics and Statistics, 55 (3), 313-28.

Chinn, M. D. \& Ito, H. (2008). A new measure of financial openness. Journal of Comparative Policy Analysis, 10 (3), 309-322.

Čihák, M., Demirgüç-Kunt, A., Feyen, E. \& Levine, R. Financial development in 205 economies, 1960-2010. NBER Working Paper, no. 18946. Cambridge: National Bureau of Economic Research.

Cypher, J. M. (2011). Mexico since NAFTA. New Labor Forum, 20 (3), 61-69.

Demetriades, P. O. \& Hussein, K. A. (1996). Does financial development cause economic growth?: time-series evidence from 16 Countries. Journal of Development Economics, 51 (2), 387-411.

De Vita, G. \& Kyaw, K. S. (2009). Growth effects of FDI and portfolio investment flows to developing countries: a disaggregated analysis by income levels. Applied Economics Letters, 16 (3), 277-283.

Durham, J. B. (2004). Absorptive capacity and the effects of foreign direct investment and equity foreign portfolio investment on economic growth. European Economic Review, 48 (2), 285-306.

Elliott, G., Rothenberg, T. I. \& Stock, I. H. (1996). Efficient test for an autoregressive unit root. Econometrica, $64(4), 813-836$.

Goldsmith, R. W. (1969). Financial structure and development. New Haven: Yale University Press.

Herman, A \& Klemm, A. (2017). Financial deepening in Mexico. IMF Working Paper, no. 17/19. Washington DC: International Monetary Fund.

Johansen, S. (1988). Statistical analysis of cointegration vectors. Journal of Economic Dynamics and Control, $12(2-3), 231-254$.

Johansen, S. \& Juselius, K. (1992). Some structural hypotheses in a multivariate cointegration analysis of purchasing power parity and uncovered interest parity for the UK. Journal of Econometrics, 53 (1-3), 211-244.

Johansen, S., Mosconi, R. \& Nielsen, B. (2000). Cointegration analysis in the presence of structural breaks in the deterministic trend. Econometrics Journal, 3 (2), 216-249.

Kehoe, T. I. \& Ruhl, K. J. (2010). Why have economic reforms in Mexico not generated growth? Journal of Economic Literature, 48 (4), 1005-1027.

King, R. G. \& Levine, R. (1993a). Finance, entrepreneurship and growth: theory and evidence. lournal of Monetary Economics, 32 (3), 513-542.

King, R. G. \& Levine, R. (1993b). Finance and growth: Schumpeter might be right. Quarterly lournal of Economics, 108 (3), 717-737.

Lane, P.R., and G.M. Milesi-Ferretti. 2007. The external wealth of nations mark II: revised and extended estimates of foreign assets and liabilities, 1970-2004. Journal of International Economics, 73 (2), 223-250. 
Lee, J. \& Strazicich, M. S. (2003). Minimum LM unit root test with two structural breaks. Review of Economics and Statistics, 85 (4), 1082-1089.

Lee, I. \& Strazicich, M. S. (2004). Minimum LM unit root test with one structural break. Appalachian State University Working Paper. Boone: Appalachian State University.

Levine, R. \& Zervos, S. (1998). Stock markets, banks and economic growth. American Economic Review 88 (3), 537-558.

Lopez, T. \& Basilio, E. (2016). Economic growth and financial development in Mexico: from a virtuous circle of a bidirectional causality to a financial subordination. In Levy, N. \& Ortiz, E. (Ed.), The financialization response to economic disequilibria. (pp. 213-230). Cheltenham: Edward Elgar Publishing.

Lucas, R. E. (1988). On the mechanics of economic development. Journal of Monetary Economics, 22 (1), 3-42.

Luintel, K. B. \& Khan, M. (1999). A quantitative reassessment of the finance-growth nexus: evidence from a multivariate VAR. Journal of Development Economics, 60 (2), 381-405.

McKinnon, R. I. (1973). Money and Capital in Economic Development. Washington DC: Brookings Institution.

Moreno-Brid, I. C., Napoles, P. R. \& Valdivia, I. C. (2005). NAFTA and the Mexican economy: a look back on a ten-year relationship. North Carolina Journal of International Law and Commercial Regulation, 30 (4), 995-1024.

Nunnenkamp, P. \& Spatz, I. (2004). FDI and economic growth in developing economies: how relevant are host-economy and industry characteristics. Transnational Corporations 13 (3), 52-86.

Pagano, M. (1993). Financial markets and growth: an overview. European Economic Review, 37 (2-3), 613-622.

Patrick, H. T. (1969). Financial development and economic growth in underdeveloped countries. Economic Development and Cultural Change, 14 (2), 174-189.

Phillips, P. C. B. \& Perron, P. (1988). Testing for a unit root in time series regression. Biometrika, 75 (2), 335-346.

Ramirez, M. D. (2006). Is foreign direct investment beneficial for Mexico?: an empirical analysis, 1960-2001. World Development, 34 (5), 802-817.

Robinson, J. (1952). The Rate of Interest and Other Essays. London: Macmillan.

Sahay, R., Cihak, M., N’Diaye, P., Barajas, A., Bi, R., Ayala, D., Gao, Y., Kyobe, A., Nguyen, L., Saborowski, C., Svirydzenka, K. and Yousefi, S. R. (2015). Rethinking financial deepening: stability and growth in emerging markets. IMF Staff Discussion Note, no. 15/08. Washington DC: International Monetary Fund.

Schumpeter, I. A. (1911). The Theory of Economic Development. Oxford: Oxford University Press.

Shaw, E. S. (1973). Financial Deepening in Economic Development. London: Oxford University Press.

Tinoco-Zermeno, M. A., Martınez, F. V. \& Torres-Preciado, V. H. (2014). Growth, bank credit, and inflation in Mexico: evidence from an ARDL-bounds testing approach. Latin America Economic Review, 23 (8), 1-22.

Toda, H. Y. \& Phillips, P. C. B. (1993). Vector autoregression and causality. Econometrica, 61 (6), 1367-1393.

Yanikkaya, H. (2003). Trade openness and economic growth: a cross-country empirical investigation. Journal of Development Economics, 72 (1), 57- 89.

Wachtel, P. (2011). The evolution of the finance growth nexus. Comparative Economic Studies, 53 (3), $475-488$. 